\title{
Cytokines induce effector T-helper cells during invasive aspergillosis; what we have learned about T-helper cells?
}

\author{
Raman Thakur ${ }^{1}$, Rajesh Anand ${ }^{2}$, Shraddha Tiwari ${ }^{1}$, Agam P. Singh ${ }^{2}$, \\ Bhupendra N. Tiwary ${ }^{3}$ and Jata Shankar ${ }^{1 *}$
}

${ }^{1}$ Department of Biotechnology and Bioinformatics, Jaypee University of Information Technology, Solan, India, ${ }^{2}$ Infectious Diseases Laboratory, National Institute of Immunology, New Delhi, India, ${ }^{3}$ Department of Biotechnology, Guru Ghasidas Vishwavidyalaya, Bilaspur, India

OPEN ACCESS

Edited by:

Frederic Lamoth,

Lausanne University Hospital,

Switzerland

Reviewed by:

Nina Khanna,

University of Basel, Switzerland Lars Tramsen,

University Hospital Frankfurt,

Germany

*Correspondence: Jata Shankar,

Department of Biotechnology and Bioinformatics, Jaypee University of Information Technology, Waknaghat, Solan 173234,

Himachal Pradesh, India jata.shankar@juit.ac.in, jata_s@yahoo.com

Specialty section: This article was submitted to Fungi and Their Interactions, a section of the journal Frontiers in Microbiology

Received: 02 January 2015 Accepted: 22 April 2015

Published: 11 May 2015

Citation:

Thakur R, Anand R, Tiwari S, Singh AP, Tiwary BN and Shankar J

(2015) Cytokines induce effector

T-helper cells during invasive aspergillosis; what we have learned

about T-helper cells?

Front. Microbiol. 6:429.

doi: 10.3389/fmicb.2015.00429
Invasive aspergillosis caused by Aspergillus species (Aspergillus fumigatus, A. flavus, and A. terreus) is life-threatening infections in immunocompromised patients. Understanding the innate and adaptive immune response particularly T-helper cells ( $T_{H}$-cells) against these Aspergillus species and how the different sub-set of $T_{H}$-cells are regulated by differentiating cytokines at primary target organ site like lung, kidney and brain is of great significance to human health. This review focuses on presentation of Aspergillus through Antigen presenting cells (APCs) to the naive CD4 ${ }^{+}$T-cells in the host. The production of differentiating/effector cytokines that activate following $T_{H}$-cells, e.g., $T_{H} 1, T_{H} 2, T_{H} 9$, and $T_{H} 17$ has been reported in association or alone in allergic or invasive aspergillosis. Chemokines (CXCL1, CXCL2, CCL1, and CCL20) and their receptors associated to these $\mathrm{T}_{\mathrm{H}}$-cells have also been observed in invasive aspergillosis. Thus, further study of these $\mathrm{T}_{\mathrm{H}}$-cells in invasive aspergillosis and other elements of adaptive immune response with Aspergillus species are required in order to have a better understanding of host response for safer and effective therapeutic outcome.

Keywords: cytokines, T-helper cells, dendritic cells, Aspergillus, antigen presenting cells, invasive aspergillosis

\section{Introduction}

Fungi are the most common microorganisms and have clinical importance. Few of them are pathogenic or opportunistic pathogen and results in morbidity and mortality to human beings. There is a rise in opportunistic fungal infections in recent years due to increased incidence of immunocompromised host (Chamilos et al., 2006; Romani, 2008). After Candida albicans, the leading causes of fungal infections in immunocompromised individuals are from Aspergillus species. Aspergillus is one of the most ubiquitous medically important opportunistic fungi (Weaver et al., 2007). The genus Aspergillus, contains about 40 species that can cause infection (Verweij and Brandt, 2007), among them A. fumigatus, A. flavus, and A. terreus are the leading cause of invasive Aspergillosis in immunocompromised individuals. These species produce conidia at a concentration of around 1-100 conidia per $\mathrm{m}^{3}$ (Barnes and Marr, 2006). Human routinely inhale hundreds of these conidia per day, despite these exposure to Aspergillus conidia, human do not develop any disease due to the clearance of conidia from lung by innate immunity especially phagocytic cells (Chamilos et al., 2006; Romani, 2008). However, due to rise in immunocompromised host, e.g., patients receiving organ 
transplant, immunosuppressive therapy for autoimmune or neoplastic disease and HIV patients, inhaled conidia if not cleared in these host, colonization of Aspergillus occurs (Stevens et al., 2000). The adaptive immune response in human responsible for conidia clearance is not well understood in immunocompetent host as well as where conidia colonize in immunocompromised host. It is worth to note that secondary metabolites (e.g., Gliotoxins, Aflatoxins) excreted by Aspergillus especially have been recognized to modulate immunological responses (Shankar, 2013). Thus, we reviewed recent advances made in immune responses against Aspergillus species in mice model studies and clinical aspergillosis patients. A. fumigatus is the prominent species, which cause $90 \%$ of Aspergillosis followed by A. flavus and A. terreus. Studies have showed that Aspergillus species associated with infection after hematopoietic stem cell transplantation include $A$. fumigatus with $56 \%$ followed by A. flavus (18.7\%) and A. terreus (16\%) (Steinbach et al., 2004; Morgan et al., 2005). The involvement of Aspergillus infection in pulmonary tuberculosis and in asthmatic patients has been reported by Denning et al. It has been estimated annually at least 372,385 patients developed chronic pulmonary aspergillosis worldwide following treated pulmonary tuberculosis (Denning et al., 2011). Similarly, around 4,837,000 patients develop Allergic bronchopulmonary aspergillosis out of 193 million adults with active asthma (Denning et al., 2013). However, in a recent study of Indian population by Agarwal et al. (2014) the estimated ABPA burden was 1.38 million out of 27.6 million adults with asthma. This review touches different aspect of antifungal immunity against aspergillosis that include antigen presenting cells (APCs), dendritic cells (DCs), fungal pattern recognition receptors (PRRs), $\mathrm{T}_{\mathrm{H}}$-cells with their subsets profile during infection associated to Aspergillus species at different site of infection, e.g., lung, kidney, and brain.

\section{Recognition of Aspergillus by the Host}

\section{Presentation of Pathogen via Soluble Receptors and Cell Bound Receptors}

After the inhalation of $A$. fumigatus conidia, they are entrapped by the lung alveoli and if they are not efficiently cleared from lung, they germinate and establish lung infection termed invasive pulmonary aspergillosis and it may also disseminates to other organs if not treated (Park and Mehrad, 2009). The recognition of A. fumigatus conidia and hyphae occurs by PRRs those include soluble receptors and cell-bound receptors. Conidial germination starts with hydrophobic layer degradation and exposure of inner cell wall components mainly polysaccharides, which includes chitin, $\beta$-glucan, mannan, and galactomannan. These are termed as pathogen associated molecular patterns (PAMP), are recognized by PRRs (Netea et al., 2006; Inoue and Shinohara, 2014). PRRs soluble receptor such as pulmonary collectins, family of C-type lectins, pentraxin-3, pulmonary surfactant proteins$\mathrm{A}$ and $\mathrm{D}$ have been reported in aspergillosis. Further, the cellbound receptors in association with aspergillosis include Toll like receptor-2 (TLR), TLR-4 and TLR-9, which potentially induce the production of pro-inflammatory cytokines and reactive oxygen species through MyD88 signaling pathway (Willment and Brown, 2008).

\section{Antigen Presenting Cells and T-cell Differentiation}

\section{Antigen Presenting Cells Triggers Cytokines Production}

The activation of the innate immunity through PRRs present on the APCs that regulate the development of T-cell. APCs express wide-array of PRRs that provides the link between adaptive and innate immunity (Park and Mehrad, 2009). APCs, dominantly DCs, are responsible for antigen monitoring and then shaping $\mathrm{T}$ cell response by secreting cytokines and chemokines. DCs express PRRs on their cell surface and endosomal compartments, which serve to recognize PAMPs. After interaction with DCs, naive Tcells are activated. The activation of T-cell response is regulated by the cytokines milieu predominantly framed by DCs (Akdis et al., 2011). Chemokines secreted by DCs recruit the phagocytic cells to infected areas to clear the Aspergillus components. APC cells, e.g., monocytes differentiate into distinct sub-populations of $\mathrm{CD}_{14}{ }^{+}$and $\mathrm{CD} 6^{+}$cells after A. fumigatus conidia infection (Serbina et al., 2009). Monocytes interact with Aspergillus antigens resulting in maturation of monocytes into macrophages or DCs. Macrophages and DCs interact with antigens and secrete effector cytokines (Osugi et al., 2002; Ramirez-Ortiz and Means, 2012). Major sub-populations of DCs are myeloid DCs, plasmacytoid DC (pDCs) and monocyte-derived DCs (Bozza et al., 2002; Osugi et al., 2002). pDC recognize the nucleic acids from A. fumigatus via TLR-9 and lead to resistance to A. fumigatus infection in mice (Ramirez-Ortiz et al., 2008). Further, monocytes migrate toward the lung to differentiate into either DCs or alveolar macrophages during invasive aspergillosis (Cramer et al., 2011; Morton et al., 2012). Monocytes express different chemokines receptor predominantly CCR2, which help in migration of monocytes from bone marrow toward lung in response to A. fumigatus infection (Serbina et al., 2009). It has been shown that monocytes expressing CCR2 in the lung involved in conidial uptake and killing (Espinosa et al., 2014). Furthermore, alveolar macrophages induce APCs to release IL $-1 \beta$ in pulmonary invasive infection (Park and Mehrad, 2009). IL-18 has also been observed in lung during invasive aspergillosis mice model (Akdis et al., 2011). Recently, it has been observed that $A$. fumigatus pulmonary challenge induces expression of the inflammasome-dependent cytokines IL- $1 \beta$ and IL-18 within the first $12 \mathrm{~h}$, while IL- $1 \alpha$ expression continually increases over at least the first $48 \mathrm{~h}$ (Caffrey et al., 2015). Moretti et al. (2014) showed in a pulmonary invasive aspergillosis model that mice injected with IL-37 prior to A. fumigatus infection has significant reduction in IL- $\beta$ production and recruitment of neutrophils and resulted in diminution in lung inflammation and damage. The anti-inflammatory activity of IL-37 has been observed as an inhibitor of the innate response. Thus, cytokines play a vital role in modulation of immune response and coordinate the innate as well as adaptive responses. APCs secrete cytokines that act on naïve T-cells leading to the differentiation of naïve $\mathrm{T}$ cells. These differentiated T-cells further secrete effector cytokines and regulate the function of $\mathrm{T}_{\mathrm{H}}$-cells. The profile of cytokine depends on the type of Aspergillus antigens, route of infection, immunological status of the host and cytokines milieu present during the interaction (Romani, 2008; Chai et al., 2010b). CD4 ${ }^{+}$ 
T-cells can be divided into distinct subtypes according to cytokine profile, and they can differentiate to $\mathrm{T}_{\mathrm{H}} 1, \mathrm{~T}_{\mathrm{H}} 2 \mathrm{~T}_{\mathrm{H}} 17, \mathrm{~T}_{\mathrm{H}} 9$, and $\mathrm{T}$ follicular effector cells (Kerzerho et al., 2013; Kara et al., 2014). On the basis of the cytokine profile, these $\mathrm{T}_{\mathrm{H}}$-cells perform distinct functions. However, it is not clear how T-follicular effector cells respond during Aspergillus infection (Wüthrich et al., 2012).

\section{Cytokines Associated with $\mathbf{T}_{\mathrm{H}} \mathbf{1}$ Type of Response}

Aspergillus fumigatus challenged intranasally in mice interacts with DCs and alveolar macrophages in the lung. Secretion of $\mathrm{T}_{\mathrm{H}} 1$ associated pro-inflammatory cytokines IL-12, IFN- $\gamma$, TNF$\alpha$, IL-18 has been observed after the challenge (Chotirmall et al., 2013). Among these, IL-12 is the prominent cytokine released from activated monocytes and macrophages in lung that help in shaping T-cell immune response. IL-12 is a heterodimeric cytokine composed of IL-12p35 and IL-12p40 polypeptides that form the bioactive IL-12p70. The heterodimer binds to the IL12 receptor composed of IL-12R $\beta 1$ and IL-12R $\beta 2$ chains and signals through STAT-4 (Shao et al., 2005). IL-12 acts on NK cells to promote IFN- $\gamma$ secretion and differentiate $\mathrm{CD} 4^{+} \mathrm{T}$-cells into $\mathrm{T}_{\mathrm{H}} 1$-cells, once $\mathrm{CD} 4{ }^{+}$cells differentiates to $\mathrm{T}_{\mathrm{H}} 1$-cells, they increase the secretion of IFN- $\gamma$, which suppress $\mathrm{T}_{\mathrm{H}} 17$ and $\mathrm{T}_{\mathrm{H}} 2$ response in the lung (Espinosa and Rivera, 2012; Camargo and Husain, 2014). IL-12, hence, is the most important regulator of $\mathrm{T}_{\mathrm{H}} 1$ response during lung infection. IL-12 deficient mice failed to generate a $\mathrm{T}_{\mathrm{H}} 1$ response, leading to increased secretion of IL-4 and IL-10 cytokines, which shifts the immune response toward $\mathrm{T}_{\mathrm{H}} 2$ pathway (Cenci et al., 1998). In A. fumigatus induced neutropenic aspergillosis in mice, NK cells can be the primary source of IFN- $\gamma$ responsible for activating phagocytic cells and direct antifungal effectors cells against A. fumigatus (Park et al., 2009). Further, patients with invasive Candida and/or Aspergillus infections, recombinant treatment of IFN- $\gamma$ in combination with antifungal drug partially restored immune function (Delsing et al., 2014). In intravenous infection of $A$. flavus mice model studies, lung and brain homogenate showed pro-inflammatory cytokines IL-12 and IFN- $\gamma$ and relative absence of IL-4, IL-23, and IL-17 suggesting a $\mathrm{T}_{\mathrm{H}} 1$ response (Anand et al., 2013, 2015). A. terreus induced invasive aspergillosis showed the presence of IL-1 $\beta$, IL-6, and reduced level of IL-10 in mice model studies. Although there is activation of $\mathrm{T}_{\mathrm{H}} 17$ type of adaptive immune response through IL- $1 \beta$ but the later is suppressed by $\mathrm{T}_{\mathrm{H}} 1$ cytokines particularly IFN- $\gamma$ (Vyas, 2011; Lass-Florl, 2012). The $\mathrm{T}_{\mathrm{H}} 1$ response is thus also mounted by $A$. terreus and there is a lack of $\mathrm{T}_{\mathrm{H}} 2$ response in contrast to $A$. fumigatus infection where $\mathrm{T}_{\mathrm{H}} 2$ promoting cytokines are observed.

\section{Cytokines Associated with $\mathbf{T}_{\mathbf{H}} \mathbf{1 7}$ Type Response}

Aspergillus fumigatus mediated infections in lung induce $\mathrm{T}_{\mathrm{H}} 17$ and $\mathrm{T}_{\mathrm{H}} 1$-cells. These cells play an important role in protection and induction of inflammation (Chai et al., 2010b). Activation of $\mathrm{T}_{\mathrm{H}}$ 17-cell depends on Dectin-1 signaling pathway. Various studies have suggested that dectin-1 deficient mice entirely activate $T_{H} 1$ cells. So Dectin-1 signaling not only serves as a positive factor to promote $T_{H} 17$ differentiation but rather act to balance $T_{H} 1$ versus $\mathrm{T}_{\mathrm{H}} 17$ differentiation. Activation of the APCs by Dectin-1, release the proinflammatory cytokines IL-1 $\beta$, IL-6, IL-23, and
IL-22 which differentiates $\mathrm{CD}^{+}{ }^{+}$T-cells to $\mathrm{T}_{\mathrm{H}}$ 17-cells, which further secretes IL-17A and IL-17F cytokines and maintain $\mathrm{T}_{\mathrm{H}} 17$ response (Werner et al., 2011). IL-23 is a member of IL-12 family, produced by phagocytic cells, macrophages and activated DCs in lung. IL-23 contains two subunits IL-12p40 and IL-23p19 and it binds to heterodimeric receptors IL-12R $\beta 1$, expressed by activated T-cells (Zelante et al., 2007). IL-6 is another important cytokine involved in regulation of $\mathrm{T}_{\mathrm{H}} 17$ response. IL-6 is a multifunctional cytokine, promote $\mathrm{T}_{\mathrm{H}} 17$-cells differentiation, inflammation and acute response (Akdis et al., 2011). During $\mathrm{T}_{\mathrm{H}} 17$ differentiation, human naïve T-cells are exposed to IL-1 $\beta$, IL-6, and IL-23 (Zelante et al., 2009; Gresnigt and van de Veerdonk, 2014). $\mathrm{T}_{\mathrm{H}} 17$ promoting cytokine IL-17 binds to IL-17RA and IL-17RC receptors expressed in lung cells, like fibroblast, epithelial cells and T-cells. After release of IL-17 from $\mathrm{T}_{\mathrm{H}} 17$-cells, it activates the neutrophils migration toward infected area and increases inflammation (Wilson et al., 2007). In A. flavus and A. terreus, the role of $\mathrm{T}_{\mathrm{H}} 17$-cells during lung infection is yet to be established.

\section{Cytokines Associated with $\mathbf{T}_{\mathbf{H}} \mathbf{2}$ Type of Response}

Aspergillus fumigatus is associated with both invasive and allergic form of aspergillosis. In case, if conidia are not cleared, they germinate to produce hyphae, which are responsible for invasion in host tissues that leads to inflammation. In a healthy human T-cells response, A. fumigatus not only evoke pro-inflammatory type of immune response via $\mathrm{T}_{\mathrm{H}} 1$ and $\mathrm{T}_{\mathrm{H}} 17$-cells but also antiinflammatory type of immune response mediated by $\mathrm{T}_{\mathrm{H}} 2$-cells (Chaudhary et al., 2010). Immune response initiated by IL-4 and IL-10 inhibits $\mathrm{T}_{\mathrm{H}} 1$ and $\mathrm{T}_{\mathrm{H}} 17$ response and increased secretion of IL-4 and IL-10 inhibits IFN- $\gamma$ and IL-12 production. $\mathrm{T}_{\mathrm{H}} 2$-cells differentiation depends on IL-4 and IL-10 and after differentiation in to $\mathrm{T}_{\mathrm{H}} 2$ cells, these cells further secretes IL-5 and IL-13 which maintain $\mathrm{T}_{\mathrm{H}} 2$ response. $\mathrm{T}_{\mathrm{H}} 2$ immune response is triggered in acute bronchopulmonary aspergillosis and also in invasive pulmonary infection during some time point of infection. IL-4 and IL-10 deficient mice show lower $A$. fumigatus burden and increased survival rates compared to wild type mouse in invasive pulmonary aspergillosis (Cenci et al., 2000). It has been shown that ESTs (L3 ribosomal protein, L7A ribosomal protein, Histone -H2A) have high sequence similarity with human counter parts suggesting molecular mimicry between human and pathogen protein (Shankar et al., 2004). However, role of these genes in eliciting allergic immune response needs investigations. In $A$. flavus mediated infection, lung homogenate showed the absence of $\mathrm{T}_{\mathrm{H}} 2$ response in a limited cytokine profile study (Anand and Tiwary, 2010). However, $\mathrm{T}_{\mathrm{H}} 2$ type response may get activated in later stages of infection in lung due to rise in IL-4 and IL10 , which suppress the $\mathrm{T}_{\mathrm{H}} 1$ response but consistent expression IFN- $\gamma$ overcomes $\mathrm{T}_{\mathrm{H}} 2$ response. In addition to $\mathrm{T}_{\mathrm{H}} 2$, the role of $\mathrm{T}_{\mathrm{H}}$ 9-cells has been shown during infection with a Virus, bacteria, parasites and fungi. $\mathrm{T}_{\mathrm{H}} 9$ response contributes to allergic inflammation during allergic aspergillosis due to A. fumigatus in mice model (Kerzerho et al., 2013). $\mathrm{T}_{\mathrm{H}}$ 9-cells develop in the presence of IL- $1 \alpha$ and TGF- $\beta$ along with $\mathrm{T}_{\mathrm{H}} 2$-cells. However, role of $\mathrm{T}_{\mathrm{H}} 9$ and $\mathrm{T}_{\mathrm{H}} 2$ response during invasive aspergillosis remains unclear. 


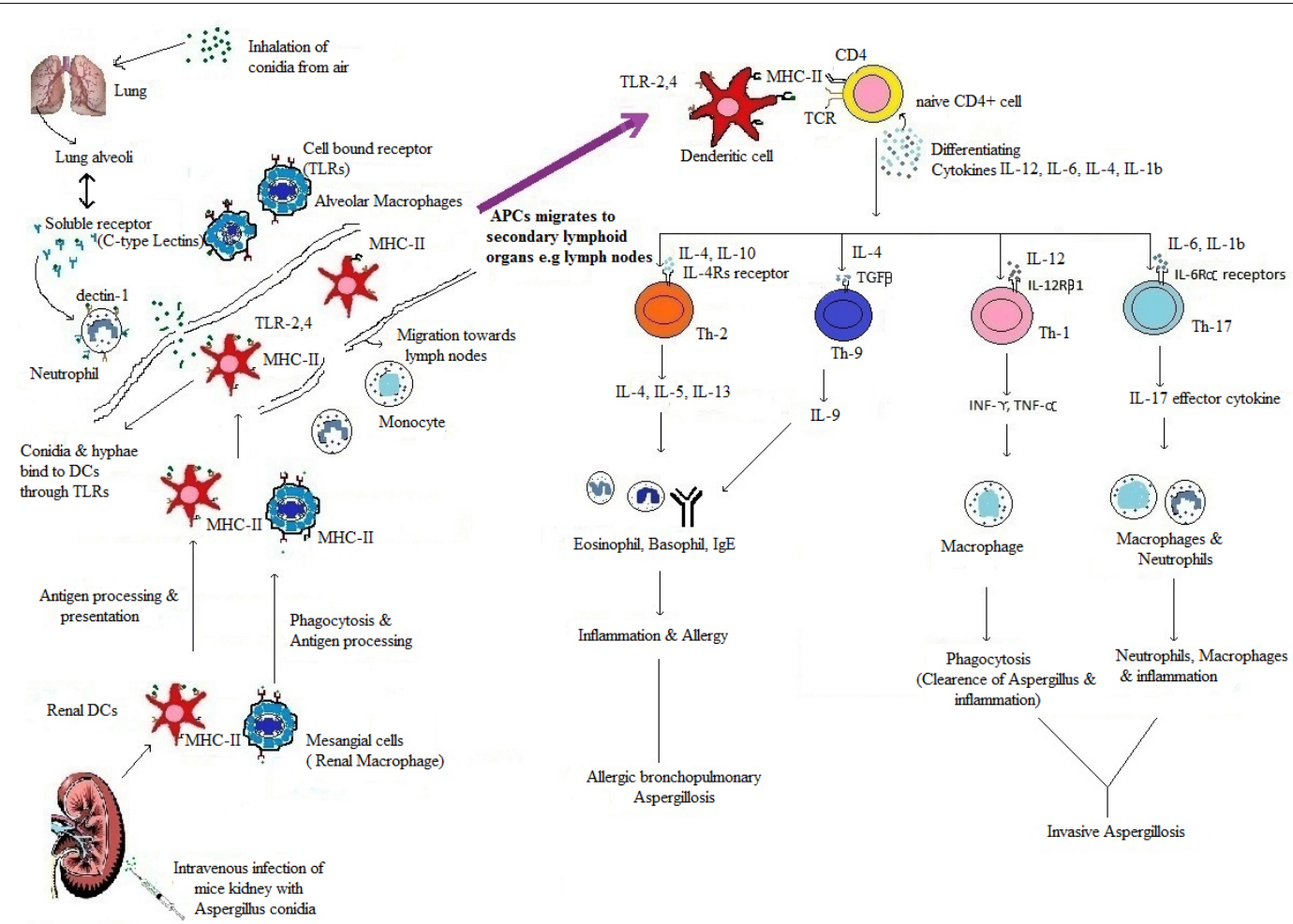

FIGURE 1 | The recognitions, processing and presentation of Aspergillus antigens to naïve CD4 ${ }^{+} \mathrm{T}_{\mathrm{H}}$-cells and Production of effector $\mathbf{T}_{\mathrm{H}}$-cells. In infected Lung and Kidney, Aspergillus antigens (conidia \& germinating conidia) are recognized by PRRs, i.e., soluble (C-type lectins) and cell bound receptors; TLR2, TLR4, and TLR9 (Netea et al., 2006). They are present on antigen presenting cells (DCs and macrophages). After recognition, antigens recognized by APCs, process and present to naiive $\mathrm{CD} 4^{+} \mathrm{T}$-cells in secondary lymphoid organs (Chai et al., 2010a). After interaction of APCs and naïve CD4 ${ }^{+}$T-cells, differential cytokines release (IL-12, IL-6, IL-4, IL-13) (Korn et al., 2009; Chai et al., 2010a) act upon CD4 ${ }^{+}$T-cells and differentiate them into effector $T_{H}$-cells. IL- 12 give rise to $T_{H} 1, I L-6, I L-1 \beta$ give rise to $T_{H} 17$ and IL-4 give rise to $\mathrm{T}_{H} 2$ effector $\mathrm{T}_{\mathrm{H}}$-cells (Murdock et al., 2011). These effector cells further secrets effector cytokines (IFN- $\gamma$, TNF- $\alpha$, IL-10, IL-5, IL-17, and IL-23) (Zelante et al., 2007) which maintain effector $T_{H}$-cells response. Figure shows summary of development of effector $T_{H}$-cells response during Lung and Kidney infection of Aspergillus. The figure is not to the scale.

\section{Is Their Co-evolution of T-helper Cells During Invasive Aspergillosis?}

In a immunocompromised mice model studies, repeated exposure of A. fumigatus conidia in hosts lead to co-evolution of $\mathrm{T}_{\mathrm{H}} 1$, $\mathrm{T}_{\mathrm{H}} 2$, and $\mathrm{T}_{\mathrm{H}} 17$ response in infected lung (Murdock et al., 2011). They have observed the presence of IFN- $\gamma$ and IL-17 in infected lung of mice along with $\mathrm{T}_{\mathrm{H}} 2$ response. These mixed responses might be occurring at different time points during progression of infection and leads to either protection or infection. $\mathrm{T}_{\mathrm{H}} 1$ and $\mathrm{T}_{\mathrm{H}} 17$ response probably leads to protection where as $\mathrm{T}_{\mathrm{H}} 2$ response further complicates the disease. $\mathrm{T}_{\mathrm{H}} 2$ response help in evasion of A. fumigatus from immune cells and further increase the IgE level, which leads to high inflammation at the site of infection. Mice model of ABPA demonstrated the $\mathrm{T}_{\mathrm{H}} 2$ cytokine profile consisting of IL-4, IL-10, and IL-5 (Latge, 1999).

\section{Interplay of Cytokines; $T_{H} 1$ or $T_{H} 2$ or $T_{H} 17$ Type of Response}

$\mathrm{T}_{\mathrm{H}}$-cells response during invasive Aspergillus depends on differentiating cytokines. $\mathrm{T}_{\mathrm{H}} 1$ response is activated by differentiating cytokine IL- 12 followed by secretion of IFN- $\gamma$. Secretion of IFN- $\gamma$ further stimulates $T_{\mathrm{H}} 1$ cells, if IFN- $\gamma$ dominates initially it suppress the other cytokines of $\mathrm{T}_{\mathrm{H}} 2$ and $\mathrm{T}_{\mathrm{H}} 17$, i.e., IL-4 and IL-17 (Harrington et al., 2005). If IL-4 dominates during initial period of Aspergillus infection, it suppresses the protective $\mathrm{T}_{\mathrm{H}} 1$ type immune response by inhibiting differential cytokine IL-12 and IFN- $\gamma$ (Harrington et al., 2005). Recognition of Aspergillus antigens by Dectin-1 signaling pathway inhibit the production of IFN$\gamma$ and IL-12 receptors suppressing $\mathrm{T}_{\mathrm{H}} 1$, which leads to differentiation of $\mathrm{T}_{\mathrm{H}} 17$-cells and production of IL-17. In this way Dectin-1 signal balances the $\mathrm{T}_{\mathrm{H}} 1$ and $\mathrm{T}_{\mathrm{H}} 17$ response through the regulation of their respective cytokines (Rivera et al., 2011; Figure 1). The development of effective $\mathrm{CD} 4^{+} \mathrm{T}_{\mathrm{H}}$-cells response not only depends upon cytokines, but also on chemokines and their receptors. Chemokines help in recruitment of leukocytes, i.e., neutrophils, monocytes and NK cells toward lung during Aspergillus infection. These cells express chemokine receptors; neutrophils contain CXCR2 chemokine receptor for ligand CXCL1 and CXCL2, monocytes contain CCR2 and CCR6 receptor for CCL2 and CCL20 ligands, where as NK cells contain CCR2 receptor for CCL2 ligand. So these chemokine ligands attract monocytes, neutrophils and NK cells to clear the Aspergillus hyphae during 
lung infection (Park and Mehrad, 2009). These chemokines receptors are also present on DCs, regulatory T-cells (Tregs) and $\mathrm{T}_{\mathrm{H}^{-}}$ cells and help in their trafficking (Bendall, 2005). In this way, there is an interdependent relationship between chemokines and cytokines that help in evolution of effector $\mathrm{T}_{\mathrm{H}}$-cells response. CCL17, a chemokine, help in trafficking of DCs, Tregs and $\mathrm{T}_{\mathrm{H}} 1$ cells toward infected area during invasive aspergillosis in response to CCR4 chemokine receptor present on these cells. Further, CCR6 receptor present on DCs and $\mathrm{T}_{\mathrm{H}}$ 17-cells help in migration of these cells in response to chemokine CCL20 (Bendall, 2005; Wüthrich et al., 2012).

\section{Conclusion}

Cytokines are important in the development of $\mathrm{CD}^{+} \mathrm{T}_{\mathrm{H}}$-cells. Understanding of trafficking of $\mathrm{CD}^{+}{ }^{+} \mathrm{T}_{\mathrm{H}}$-cells and their regulation through differentiating/effector cytokines during invasive

\section{References}

Agarwal, R., Denning, D. W., and Chakrabarti, A. (2014). Estimation of the burden of chronic and allergic pulmonary aspergillosis in India. PLoS ONE 9:e114745. doi: 10.1371/journal.pone.0114745

Akdis, M., Burgler, S., Crameri, R., Eiwegger, T., Fujita, H., Gomez, E., et al. (2011). Interleukins, from 1 to 37, and interferon-gamma: receptors, functions, and roles in diseases. J. Allergy Clin. Immunol. 127, 701-721 e701-e770. doi: 10.1016/j.jaci. 2010.11.050

Anand, R., Shankar, J., Singh, A. P., and Tiwary, B. N. (2013). Cytokine milieu in renal cavities of immunocompetent mice in response to intravenous challenge of Aspergillus flavus leading to aspergillosis. Cytokine 61, 63-70. doi: 10.1016/ j.cyto.2012.08.024

Anand, R., Shankar, J., Tiwary, B. N., and Singh, A. P. (2015). Aspergillus flavus induces granulomatous cerebral aspergillosis in mice with display of distinct cytokine profile. Cytokine 72, 166-172. doi: 10.1016/j.cyto.2015.01.006

Anand, R., and Tiwary, B. N. (2010). Th1 and Th2 cytokines in a self-healing primary pulmonary Aspergillus flavus infection in BALB/c mice. Cytokine 52, 258-264. doi: 10.1016/j.cyto.2010.07.428

Barnes, P. D., and Marr, K. A. (2006). Aspergillosis: spectrum of disease, diagnosis, and treatment. Infect. Dis. Clin. North Am. 20, 545-561, vi. doi: 10.1016/j.idc. 2006.06.001

Bendall, L. (2005). Chemokines and their receptors in disease. Histol. Histopathol. 20, 907-926

Bozza, S., Gaziano, R., Spreca, A., Bacci, A., Montagnoli, C., Di Francesco, P., et al. (2002). Dendritic cells transport conidia and hyphae of Aspergillus fumigatus from the airways to the draining lymph nodes and initiate disparate Th responses to the fungus. J. Immunol. 168, 1362-1371. doi: 10.4049/jimmunol.168.3.1362

Caffrey, A. K., Lehmann, M. M., Zickovich, J. M., Espinosa, V., Shepardson, K. M., Watschke, C. P., et al. (2015). IL-1alpha signaling is critical for leukocyte recruitment after pulmonary Aspergillus fumigatus challenge. PLoS Pathog. 11:e1004625. doi: 10.1371/journal.ppat.1004625

Camargo, J. F., and Husain, S. (2014). Immune correlates of protection in human invasive aspergillosis. Clin. Infect. Dis. 59, 569-577. doi: 10.1093/cid/ciu337

Cenci, E., Mencacci, A., Bacci, A., Bistoni, F., Kurup, V. P., and Romani, L. (2000). T cell vaccination in mice with invasive pulmonary aspergillosis. J. Immunol. 165, 381-388. doi: 10.4049/jimmunol.165.1.381

Cenci, E., Mencacci, A., Fe D’ostiani, C., Del Sero, G., Mosci, P., Montagnoli, C., et al. (1998). Cytokine- and T helper-dependent lung mucosal immunity in mice with invasive pulmonary aspergillosis. J. Infect. Dis. 178, 1750-1760. doi: 10.1086/314493

Chai, L., Netea, M. G., Teerenstra, S., Earnest, A., Vonk, A. G., Schlamm, H. T., et al. (2010a). Early proinflammatory cytokines and C-reactive protein trends as predictors of outcome in invasive Aspergillosis. J. Infect. Dis. 202, 1454-1462. doi: $10.1086 / 656527$ aspergillosis will be crucial for the targeted immunotherapy. Overall, cytokines and chemokines may serve as prognostic biomarkers that could be followed to assess the effectiveness of treatment response during invasive aspergillosis. Measurement of selected cytokines in the blood samples of aspergillosis patients may be a promising tool for the monitoring of treatment responses. Also, manipulation of cytokine response e. g, IFN- $\gamma$ or IFN- $\gamma$ in combination with antifungal drug, IL-37, may be a future avenue for the development of better therapeutic against invasive aspergillosis.

\section{Acknowledgments}

Authors are thankful to Department of Biotechnology and Bioinformatics, Jaypee University of Information Technology, Solan, Himachal Pradesh, India, for financial support to Ph.D. students RT and ST.

Chai, L. Y., Van De Veerdonk, F., Marijnissen, R. J., Cheng, S. C., Khoo, A. L. Hectors, M., et al. (2010b). Anti-Aspergillus human host defence relies on type $1 \mathrm{~T}$ helper (Th1), rather than type $17 \mathrm{~T}$ helper (Th17), cellular immunity. Immunology 130, 46-54. doi: 10.1111/j.1365-2567.2009.03211.x

Chamilos, G., Luna, M., Lewis, R. E., Bodey, G. P., Chemaly, R., Tarrand, J. J., et al. (2006). Invasive fungal infections in patients with hematologic malignancies in a tertiary care cancer center: an autopsy study over a 15-year period (1989-2003). Haematologica 91, 986-989.

Chaudhary, N., Staab, J. F., and Marr, K. A. (2010). Healthy human T-Cell Responses to Aspergillus fumigatus antigens. PLoS ONE 5:e9036. doi: 10.1371/journal. pone.0009036

Chotirmall, S. H., Al-Alawi, M., Mirkovic, B., Lavelle, G., Logan, P. M., Greene, C. M., et al. (2013). Aspergillus-associated airway disease, inflammation, and the innate immune response. Biomed. Res. Int. 2013, 723129. doi: 10.1155/2013/ 723129

Cramer, R. A., Rivera, A., and Hohl, T. M. (2011). Immune responses against Aspergillus fumigatus: what have we learned? Curr. Opin. Infect. Dis. 24, 315-322. doi: 10.1097/QCO.0b013e328348b159

Delsing, C. E., Gresnigt, M. S., Leentjens, J., Preijers, F., Frager, F. A., Kox, M., et al. (2014). Interferon-gamma as adjunctive immunotherapy for invasive fungal infections: a case series. BMC Infect. Dis. 14:166. doi: 10.1186/1471-2334-14-166

Denning, D. W., Pleuvry, A., and Cole, D. C. (2011). Global burden of chronic pulmonary aspergillosis as a sequel to pulmonary tuberculosis. Bull. World Health Organ. 89, 864-872. doi: 10.2471/blt.11.089441

Denning, D. W., Pleuvry, A., and Cole, D. C. (2013). Global burden of allergic bronchopulmonary aspergillosis with asthma and its complication chronic pulmonary aspergillosis in adults. Med. Mycol. 51, 361-370. doi: 10.3109/13693786. 2012.738312

Espinosa, V., Jhingran, A., Dutta, O., Kasahara, S., Donnelly, R., Du, P., et al. (2014). Inflammatory monocytes orchestrate innate antifungal immunity in the lung. PLoS Pathog. 10:e1003940. doi: 10.1371/journal.ppat.1003940

Espinosa, V., and Rivera, A. (2012). Cytokines and the regulation of fungus-specific CD4 T cell differentiation. Cytokine 58, 100-106. doi: 10.1016/j.cyto.2011.11.005

Gresnigt, M. S., and van de Veerdonk, F. L. (2014). The role of interleukin-1 family members in the host defence against Aspergillus fumigatus. Mycopathologia 178, 395-401. doi: 10.1007/s11046-014-9776-y

Harrington, L. E., Hatton, R. D., Mangan, P. R., Turner, H., Murphy, T. L., Murphy, K. M., et al. (2005). Interleukin 17-producing $\mathrm{CD}^{+}{ }^{+}$effector $\mathrm{T}$ cells develop via a lineage distinct from the T helper type 1 and 2 lineages. Nat. Immunol. 6 , 1123-1132. doi: 10.1038/ni1254

Inoue, M., and Shinohara, M. L. (2014). Clustering of pattern recognition receptors for fungal detection. PLoS Pathog. 10:e1003873. doi: 10.1371/journal. ppat. 1003873

Kara, E. E., Comerford, I., Fenix, K. A., Bastow, C. R., Gregor, C. E., Mckenzie, D. R., et al. (2014). Tailored immune responses: novel effector helper $\mathrm{T}$ cell 
subsets in protective immunity. PLoS Pathog. 10:e1003905. doi: 10.1371/journal.ppat.1003905

Kerzerho, J., Maazi, H., Speak, A. O., Szely, N., Lombardi, V., Khoo, B., et al. (2013). Programmed cell death ligand 2 regulates TH9 differentiation and induction of chronic airway hyperreactivity. J. Allergy Clin. Immunol. 131, 1048-1057, 1057 e1041-e1042. doi: 10.1016/j.jaci.2012.09.027

Korn, T., Bettelli, E., Oukka, M., and Kuchroo, V. K. (2009). IL-17 and Th17 Cells. Annu. Rev. Immunol. 27, 485-517. doi: 10.1146/annurev.immunol.021908. 132710

Lass-Florl, C. (2012). Aspergillus terreus: how inoculum size and host characteristics affect its virulence. J. Infect. Dis. 205, 1192-1194. doi: 10.1093/infdis/jis185

Latge, J. P. (1999). Aspergillus fumigatus and aspergillosis. Clin. Microbiol. Rev. 12, 310-350.

Moretti, S., Bozza, S., Oikonomou, V., Renga, G., Casagrande, A., Iannitti, R. G., et al. (2014). IL-37 inhibits inflammasome activation and disease severity in murine aspergillosis. PLoS Pathog. 10:e1004462. doi: 10.1371/journal.ppat. 1004462

Morgan, J., Wannemuehler, K. A., Marr, K. A., Hadley, S., Kontoyiannis, D. P., Walsh, T. J., et al. (2005). Incidence of invasive aspergillosis following hematopoietic stem cell and solid organ transplantation: interim results of a prospective multicenter surveillance program. Med. Mycol. 43(Suppl. 1), S49-S58. doi: 10.1080/13693780400020113

Morton, C. O., Bouzani, M., Loeffler, J., and Rogers, T. R. (2012). Direct interaction studies between Aspergillus fumigatus and human immune cells; what have we learned about pathogenicity and host immunity? Front. Microbiol. 3:413. doi: 10.3389/fmicb.2012.00413

Murdock, B. J., Shreiner, A. B., Mcdonald, R. A., Osterholzer, J. J., White, E. S., Toews, G. B., et al. (2011). Coevolution of TH1, TH2, and TH17 responses during repeated pulmonary exposure to Aspergillus fumigatus conidia. Infect. Immun. 79, 125-135. doi: 10.1128/iai.00508-10

Netea, M. G., Ferwerda, G., Van Der Graaf, C. A., Van Der Meer, J. W., and Kullberg, B. J. (2006). Recognition of fungal pathogens by toll-like receptors. Curr. Pharm. Des. 12, 4195-4201. doi: 10.2174/138161206778743538

Osugi, Y., Vuckovic, S., and Hart, D. N. (2002). Myeloid blood CD11c ${ }^{+}$dendritic cells and monocyte-derived dendritic cells differ in their ability to stimulate $\mathrm{T}$ lymphocytes. Blood 100, 2858-2866. doi: 10.1182/blood.V100.8.2858

Park, S. J., Hughes, M. A., Burdick, M., Strieter, R. M., and Mehrad, B. (2009). Early NK cell-derived IFN-\{gamma\} is essential to host defense in neutropenic invasive aspergillosis. J. Immunol. 182, 4306-4312. doi: 10.4049/jimmunol.0803462

Park, S. J., and Mehrad, B. (2009). Innate immunity to Aspergillus species. Clin. Microbiol. Rev. 22, 535-551. doi: 10.1128/cmr.00014-09

Ramirez-Ortiz, Z. G., and Means, T. K. (2012). The role of dendritic cells in the innate recognition of pathogenic fungi (A. fumigatus, C. neoformans, and $C$. albicans). Virulence 3, 635-646. doi: 10.4161/viru.22295

Ramirez-Ortiz, Z. G., Specht, C. A., Wang, J. P., Lee, C. K., Bartholomeu, D. C., Gazzinelli, R. T., et al. (2008). Toll-like receptor 9-dependent immune activation by unmethylated CpG motifs in Aspergillus fumigatus DNA. Infect. Immun. 76, 2123-2129. doi: 10.1128/iai.00047-08

Rivera, A., Hohl, T. M., Collins, N., Leiner, I., Gallegos, A., Saijo, S., et al. (2011). Dectin-1 diversifies Aspergillus fumigatus-specific $\mathrm{T}$ cell responses by inhibiting $\mathrm{T}$ helper type $1 \mathrm{CD} 4 \mathrm{~T}$ cell differentiation. J. Exp. Med. 208, 369-381. doi: 10.1084/jem.20100906

Romani, L. (2008). Cell mediated immunity to fungi: a reassessment. Med. Mycol. 46, 515-529. doi: 10.1080/13693780801971450

Serbina, N. V., Cherny, M., Shi, C., Bleau, S. A., Collins, N. H., Young, J. W., et al. (2009). Distinct responses of human monocyte subsets to Aspergillus fumigatus conidia. J. Immunol. 183, 2678-2687. doi: 10.4049/jimmunol.0803398
Shankar, J. (2013). An overview of toxins in Aspergillus associated with pathogenesis. Int. J. Life Sci. Biotechnol. Pharm. Res. 2, 16-31.

Shankar, J., Nigam, S., Saxena, S., Madan, T., and Sarma, P. U. (2004). Identification and assignment of function to the genes of Aspergillus fumigatus expressed at 37 degrees C. J. Eukaryot. Microbiol. 51, 428-432. doi: 10.1111/j.1550-7408.2004. tb00390.x

Shao, C., Qu, J., He, L., Zhang, Y., Wang, J., Zhou, H., et al. (2005). Dendritic cells transduced with an adenovirus vector encoding interleukin-12 are a potent vaccine for invasive pulmonary aspergillosis. Genes Immun. 6, 103-114. doi: 10.1038/sj.gene.6364167

Steinbach, W. J., Benjamin, D. K. Jr., Kontoyiannis, D. P., Perfect, J. R., Lutsar, I., et al. (2004). Infections due to Aspergillus terreus: a multicenter retrospective analysis of 83 cases. Clin. Infect. Dis. 39, 192-198. doi: 10.1086/421950

Stevens, D. A., Kan, V. L., Judson, M. A., Morrison, V. A., Dummer, S., Denning, D. W., et al. (2000). Practice guidelines for diseases caused by Aspergillus. Infectious Diseases Society of America. Clin. Infect. Dis. 30, 696-709. doi: 10.1086/ 313756

Verweij, P. E., and Brandt, M. E. (2007). Aspergillus, Fusarium and Other Opportunistic Moniliaceous Fungi. Washington, DC: ASM Press.

Vyas, J. M. (2011). The duality of Aspergillus terreus: differential immune responses to distinct conidia. Virulence 2, 181-184. doi: 10.4161/viru.2.3.16613

Weaver, C. T., Hatton, R. D., Mangan, P. R., and Harrington, L. E. (2007). IL17 family cytokines and the expanding diversity of effector $\mathrm{T}$ cell lineages. Annu. Rev. Immunol. 25, 821-852. doi: 10.1146/annurev.immunol.25.022106. 141557

Werner, J. L., Gessner, M. A., Lilly, L. M., Nelson, M. P., Metz, A. E., Horn, D., et al. (2011). Neutrophils produce interleukin 17A (IL-17A) in a dectin-1- and IL-23-dependent manner during invasive fungal infection. Infect. Immun. 79, 3966-3977. doi: 10.1128/IAI.05493-11

Willment, J. A., and Brown, G. D. (2008). C-type lectin receptors in antifungal immunity. Trends Microbiol. 16, 27-32. doi: 10.1016/j.tim.2007.10.012

Wilson, N. J., Boniface, K., Chan, J. R., Mckenzie, B. S., Blumenschein, W. M., Mattson, J. D., et al. (2007). Development, cytokine profile and function of human interleukin 17-producing helper T cells. Nat. Immunol. 8, 950-957. doi: $10.1038 /$ ni1497

Wüthrich, M., Deepe, G. S., Jr., and Klein, B. (2012). Adaptive immunity to fungi. Annu. Rev. Immunol. 30, 115-148. doi: 10.1146/annurev-immunol-020711074958

Zelante, T., Bozza, S., De Luca, A., D’angelo, C., Bonifazi, P., Moretti, S., et al. (2009). Th17 cells in the setting of Aspergillus infection and pathology. Med. Mycol. 47(Suppl. 1), S162-S169. doi: 10.1080/13693780802140766

Zelante, T., De Luca, A., Bonifazi, P., Montagnoli, C., Bozza, S., Moretti, S., et al. (2007). IL-23 and the Th17 pathway promote inflammation and impair antifungal immune resistance. Eur. J. Immunol. 37, 2695-2706. doi: 10.1002/eji. 200737409

Conflict of Interest Statement: The authors declare that the research was conducted in the absence of any commercial or financial relationships that could be construed as a potential conflict of interest.

Copyright $\odot 2015$ Thakur, Anand, Tiwari, Singh, Tiwary and Shankar. This is an open-access article distributed under the terms of the Creative Commons Attribution License (CC BY). The use, distribution or reproduction in other forums is permitted, provided the original author(s) or licensor are credited and that the original publication in this journal is cited, in accordance with accepted academic practice. No use, distribution or reproduction is permitted which does not comply with these terms. 